\title{
Review of Jonathan Wight's Ethics in economics: an introduction to moral frameworks. Stanford: Stanford University Press, 2015, 275 pp.
}

\author{
GeORGE F. DEMARTINO \\ University of Denver
}

For many years now those of us looking for a text to use in courses on ethics and economics and have had to rely primarily on Hausman and McPherson's Economic analysis, moral philosophy, and public policy (2006). In my experience that largely comprehensive work has proven to be a far better guide for the instructor than for students who are new to the study of moral and political philosophy, or to the practice of normative engagement. Working with upper level undergraduate and graduate students in a school of international studies-where students are typically more widely trained than in economics departments-I've found the book too choppy in its presentation (too detailed in some respects and too rushed in others, which interferes with its narrative flow) and ultimately discouraging for students trying to wrap their minds around the central concepts of moral philosophy. Though there are sections of the book that are superb-its extended treatment of the infamous Larry Summers World Bank memo that advocates dumping pollution in poor countries is analytically and pedagogically first ratethe book now serves me primarily as a useful reference in my own research and teaching. It is no longer featured on my syllabi.

In part for this reason I was eager to read Jonathan Wight's Ethics in economics, to see whether it might provide a viable alternative for introducing students to the field. In fact, it does. But the book is more than the introductory text that it purports to be. The book has deepened my own reckoning with normative and economic theory, human behavior, and policy adjudication. For the sake of the many students who have passed through my courses over the years, I only wish the book had appeared a decade or two earlier.

Ethics in economics covers familiar ground (before introducing innovative ideas), but in ways that are both wonderfully accessible and directly relevant to economics. For instance, the three chapters in Part I demonstrate why ethics matters in economics, and why even positive 
economics is value laden. This is something many economists are reluctant to concede, even following the persuasive work by Amartya Sen (1987) and others. Here Wight explores consequentialist, deontological, and virtue-based moral frameworks. The presentation is analytically sharp but also intuitive. Within the first dozen pages Wight has already introduced a concrete case that is both engaging and instructive-the infamous decision in the 1970s by GM not to repair a known problem with the gas tank placement on the Chevy Malibu that could and did cause explosions in certain crash situations that led to serious injuries and death. Wight exploits the case to convey the principal features of alternative moral theories and to tease out the distinctions between them. Having presented the frameworks, many normative theorists - and especially economists-would rush toward a forced normative choice of one framework over others as the uniquely appropriate lens by which to judge behavior, and economic policies and outcomes. ${ }^{1}$ In economics, after all, we tend toward what philosopher Howard Radest (1997) calls "moral geometry"-the reduction of baffling ethical problems via a neat, analytically tractable machinery that yields unambiguous policy directives. Hence our profession's deep attachment to Pareto, Kaldor-Hicks, cost-benefit analysis, or social welfare functions. Given his previous work on Adam Smith, one might have expected Wight to reject consequentialist and deontological ethics in toto in favor of virtue ethics as the singly appropriate and defensible framework to guide agents' decision-making and ground normative economics.

Wight does not take that route, however. ${ }^{2}$ Instead, a central objective (and certainly the most novel feature) of the book is to argue that any mono-theoretic approach is just as stunted and harmful in normative theory as it is in positive theory. Wight's "ethical pluralism" entails "a more elaborate structure" that considers

the likelihood that people make choices within a pluralist moral ecosystem, that is, some mix of considering outcomes, conforming actions to principles, and exploring character or virtue as part of meaning and identity (p. 17).

\footnotetext{
${ }^{1}$ I include myself among those economists who exhibit this tendency. See DeMartino (2001), where I explore the capabilities framework of Amartya Sen and Martha Nussbaum and argue that it provides a better foundation for global policy assessment than neoclassical consequentialist welfarism.

${ }^{2}$ Neither, as Wight (p. 211) informs us, did Smith. Wight's Smith is a pragmatist who understood the "interplay of values and principles."
} 
Wight seeks to persuade us that ethical pluralism is central to good practice in both positive and normative economics. Following Sen (1987), he argues that an appreciation of ethical complexity can help positive economics to model human behavior far more satisfactorily than any approach that presumes that humans act according to some narrow motivation, like self-interest. To this end, chapter 8 (evocatively titled “The Science Behind Adam Smith's Ethics") surveys findings from behavioral economics and neuroeconomics that demonstrate a rich diversity of human sensibilities and motivations. ${ }^{3}$ Evidence from the new research ought to put to rest the idea that Homo economicus provides an adequate conception of human behavior. This positive insight helps to sustain a set of central normative claims-that ethical pluralism provides a more adequate and compelling basis for normative assessment of individual behaviors and government policy. A recurring theme of the book is that "seemingly different principles are at times necessary for the operation of another" (p. 17). Economic agents cannot be good consequentialists, for instance, if they do not at the same time recognize a set of duties (to respect the rights of others, for instance) as they go about maximizing the outcomes they value, and if they do not also cultivate an appropriate set of virtues. Wight locates this insight even in Milton Friedman's famous "Social Responsibility of Business" essay (1970), so often taken as paean to strict, hard-headed, unapologetic consequentialism. ${ }^{4}$ If it is in fact true that alternative moral frameworks "complete" rather "compete with" (p. 18) each other as humans fashion their behavior, then ought we not recognize moral

\footnotetext{
${ }^{3}$ Absent here, however, is consideration of findings from the new field of behavioral ethics, which demonstrate that virtuous people often violate their own moral precepts and then fail to recognize their transgressions after the fact. See Bazerman and Tenbrunsel (2011) for a comprehensive overview of the field. The research is consistent with many of Wight's claims, especially the idea that moral behavior requires more than consequentialist reasoning or acting in accordance with duties since people are wonderfully adept at reconciling consequential reasoning and moral duties with even egregious behavior.

${ }^{4}$ Wight draws our attention to what I'll call the 'Friedmanian Proviso,' that corporate managers must seek to maximize corporate profit "while conforming to the basic rules of the society, both those embodied in law and those embodied in ethical custom" (Wight, 13). As with provisos more generally, (such as the 'Lockean Proviso' against the monopolization of vital resources, see Nozick 1974), this one is often overlooked by advocates of Friedman's position on the obligations of corporate managers. Wight's treatment of Friedman strikes me as too generous, however. If there is an ethical duty to respect both the law and ethical custom, and the law permits and custom instructs corporate managers to attend in their decision-making to the broader needs of society and not just shareholders-wasn't it this ethical custom to which Friedman was objecting in the essay? - then we have a clear renunciation of Friedman's central dictate to managers to maximize profit.
} 
pluralism as an appropriate grounding for normative assessment? Up until recently and too often even today in normative moral philosophy the tendency is to disparage ethical pluralism (in our students and others) as a sign of moral laziness, immaturity, or cowardice; as evidence of unwillingness to judge behaviors and outcomes by reference to the uniquely correct framework. Wight's response is to encourage us to brave ethical pluralism even if doing so sacrifices ethical closure in particular cases, and consistency across them.

Part II of the book provides one of the best introductory treatments of normative economics now available. Its three chapters provide an accessible, engaging account of the standard treatment of preferencebased welfare in economics before turning to the concept of Pareto and Kaldor-Hicks efficiency and the practice of cost-benefit analysis. Wight's assessment of standard neoclassical economics is respectful but hardly slavish. Indeed, chapter 5 on cost-benefit analysis and chapter 6 on criticisms of the preference satisfaction view of welfare bring together and extend many of the most compelling objections that have been offered to date against the neoclassical orthodoxy by critics on the liberal left (Sen) and right (Buchanan). For instance, Wight argues that as an application of Kaldor-Hicks, cost-benefit analysis shifts focus away from actual preference satisfaction and seeks to maximize capacity for preference satisfaction; and from actual to potential Pareto improvements. Equally problematic, it entails compulsion rather than consensual exchange. Citing Buchanan (1999 [1969]) Wight argues that compulsion makes it impossible to measure the actual opportunity costs associated with any policy adjustment that entails harms to economic actors. How can we know how much harm the loss of a valued good entails if there is no genuine opportunity for the affected party to negotiate a price at which she is willing to forego the good?

\footnotetext{
${ }^{5}$ I'm thinking here, for instance, of the purported moral inconsistency inferred by utilitarians from the contradictory findings between the "trolley" problem (should one pull a lever that will redirect an oncoming trolley from a track where it will kill five people to one where it will kill just one?) and the "bridge overpass" problem (should one push a heavy man with a large backpack off a bridge overpass to prevent a trolley from killing five people?). Respondents tend to answer yes in the first but no in the second case. For strict consequentialists, the inconsistency reflects an indefensible distinction-between harming as a side-effect and harming as means to bring about a good outcome-that interferes with solid, cool-headed ethical judgment. Among others, Sen (1992) has pushed back against this tendency to essentialize any one normative standard (or procedure) against which to judge behavior and economic outcomes.
} 
The insight regarding compulsion leads to another, which is particularly troublesome for the standard view that takes cost-benefit analysis to be a universally applicable policy decision-rule. Compulsion is justifiable only within institutional settings that provide sufficient support for democratic governance over the ground rules of economic engagement; individual rights; and a rule of law that encompasses adequate due process protections. Only in such contexts can we possibly infer that those harmed by Kaldor-Hicks efficient government initiatives (such as the use of eminent domain to seize private property so that it can serve more valuable purposes) have consented in advance to arrangements that sometimes induce harm to some so as to promote the general good. Moreover, only in such contexts can we conclude that the harms imposed are not the result of practices and procedures that citizens would deem unjust or otherwise illegitimate. Wight reminds us that "[w]hat is compulsory in a country with due process laws becomes coercive in a state lacking basic safeguards" (p. 90). He cites the Three River Gorges Dam in China as an egregious example, where the institutional supports for the legitimacy of compulsion are lacking, and where it cannot be claimed that the project is legitimated by the fact that its benefits are predicted to exceed its (massive) costs. Wight concludes the discussion with this question:

Without free speech, political parties, fair courts, or the right to emigrate, citizens in China lack the ability to set the rules for public policy making and to ensure that they are fairly enforced. What is the meaning of "efficiency" in this setting (p. 91)?

I'm on board with this claim, and I can only hope that leading economists will take heed when they find themselves advising government lacking basic civil rights. But I worry that the focus on the boogeyman China in Wight's text lets the profession off the hook too easily in its defaulting to cost-benefit analysis as a legitimate decision rule in other contexts. As an instructor teaching the book I'd push my students to examine the degree to which the same critique applies today in the US, where (as Wight acknowledges, p. 86) neoclassical welfarism rather than legal rights now so often infuses judicial decision-making and where historically unprecedented inequality and the escalating capture of the state by elites undermine democratic procedures for ensuring consent and due process when some are forced to suffer for the presumed benefit of society. 
In Part III, Wight explores "topics in ethics and economics." These chapters are not to be skipped, as they provide some of the most compelling of the book's insights. For instance, chapter 7 provides a comprehensive account of the moral limits to the market, organized around arguments pertaining to a) the intrinsic nature of certain goods, and $b$ ) the background conditions under which market exchanges take place. Regarding intrinsic matters, the chapter surveys inter alia claims pertaining to "moral goods," and the problem of moral crowding out. For instance, voluntarism sometimes dissipates when financial incentives are offered to increase solidaristic behaviors, like the practice of donating blood. Background conditions that call market exchange into question comprise personal and even certain social relationships, vulnerability that can lead to exploitation, and discrimination and other mechanisms that can generate repugnant market outcomes. Neoclassical price theory has displaced 'just price' by virtue of its conception of consumer sovereignty which posits that restrictions on what might appear to be unequal exchange can only harm most the agent who is most desperate to conclude the contract. Wight rescues the concept of just price by pointing to its normative grounding in evolving community conceptions of basic fairness. He identifies its continuing salience today in contexts ranging from Mayan markets in which price setting is biased toward the most vulnerable party, to the Living Wage Movements in major US cities, to the global anti-sweatshop movement. ${ }^{6}$

The book's concluding chapter deepens the argument for ethical pluralism. Here Wight amplifies the presentation of what he calls "3 dimensional thinking" on ethical matters. The perspective on offer recognizes the value of virtue, duty and consequences in shaping human behavior and in normative assessment of practices and policies. The 3-D approach also recognizes that each normative framework is internally heterogeneous. Consequentialist analysis can range over preference satisfaction, wealth enhancement, harm minimization, inequality reduction, and so forth. Virtues and duties are similarly complex. By this point in the text Wight has tried to inoculate us against the expectation of or desire for a singly dominant ethical principle to guide us in our individual behaviors or our professional practice.

Will students find ethical pluralism ultimately satisfying? Will it promote a willingness to live with ethical complexity when they might

\footnotetext{
${ }^{6}$ Chapters 9-11 explore equally pressing topics. These include the financial crisis of 2008 , and the contested matter of inequality and justice.
} 
have hoped for moral geometry? Or will it lead to moral bewilderment and, even worse, skepticism toward the claim that normative theory has anything to add to their personal development or their economic literacy?

My own experience suggests that the students who self-select into courses on normative economics are far more open to ethical complexity than the median economist. They are eager to learn how economists think about normative matters, but they are not typically willing to submit to welfarist preference satisfaction simply because it is the predominant approach to normative assessment in economics today. They are open to the kinds of criticisms of ethical monotheoretism that Wight offers here, even if the confrontation with pluralism generates plenty of moments of exasperation. The challenge for the instructor using a book like Wight's will be to nurture students' appreciation of the power and challenge of ethical pluralism without letting them slide too easily into simplistic ethical relativism. That challenge may be difficult to manage, but the rewards to at least some students who leave the course with greater ethical awareness and enhanced capacity for moral judgment could more than repay the effort.

\section{REFERENCES}

Bazerman, Max H. and Ann. E. Tenbrunsel. 2011. Blind spots: why we fail to do what's right and what to do about it. Princeton: Princeton University Press.

Buchanan, James. M. 1999 [1969]. Cost and choice: an inquiry in economic theory. Indianapolis: Liberty Fund.

DeMartino, George F. 2001. Global economy, global justice: theoretical objections and policy alternatives to neoliberalism. London: Routledge.

Friedman, Milton. 1970. The social responsibility of business is to increase its profits. The New York Times Magazine, September 13.

Hausman, Daniel. M. and Michael S. McPherson. 2006. Economic analysis, moral philosophy, and public policy, second ed. Cambridge: Cambridge University Press.

Nozick, R. 1974. Anarchy, State and Utopia. New York, NY: Basic Books.

Radest, Howard B. 1997. First, do no harm! Medical ethics and moral education. Humanism Today, 11.

Sen, Amartya. 1987. On ethics and economics. Malden (MA): Blackwell.

Sen, Amartya. 1992. Inequality Reexamined. Cambridge (MA): Harvard University Press.

George F. DeMartino is professor of international economics at the Josef Korbel School of International Studies of the University of Denver. DeMartino's research interests include global political economy, and the ethical foundations of economic theory and policy. Over the past several 
years he has advocated the need to develop a professional ethics for economics, including in such works as The economist's oath: on the need for and content of professional economic ethics (2011, Oxford University Press) and the Oxford handbook of professional economic ethics (2016, with Deirdre McCloskey).

Contact e-mail: <george.demartino@du.edu> 